\title{
Reducing calorie sales from supermarkets - 'silent' reformulation of retailer-brand food products
}

\author{
Jørgen Dejgård Jensen ${ }^{1 *}$ and Iben Sommer ${ }^{2}$
}

\begin{abstract}
Background: Food product reformulation is seen as one among several tools to promote healthier eating. Reformulating the recipe for a processed food, e.g. reducing the fat, sugar or salt content of the foods, or increasing the content of whole-grains, can help the consumers to pursue a healthier life style. In this study, we evaluate the effects on calorie sales of a 'silent' reformulation strategy, where a retail chain's private-label brands are reformulated to a lower energy density without making specific claims on the product.
\end{abstract}

Methods: Using an ecological study design, we analyse 52 weeks' sales data - enriched with data on products' energy density - from a Danish retail chain. Sales of eight product categories were studied. Within each of these categories, specific products had been reformulated during the 52 weeks data period. Using econometric methods, we decompose the changes in calorie turnover and sales value into direct and indirect effects of product reformulation.

Results: For all considered products, the direct effect of product reformulation was a reduction in the sale of calories from the respective product categories - between 0.5 and 8.2\%. In several cases, the reformulation led to indirect substitution effects that were counterproductive with regard to reducing calorie turnover. However, except in two insignificant cases, these indirect substitution effects were dominated by the direct effect of the reformulation, leading to net reductions in calorie sales between -3.1 and $7.5 \%$. For all considered product reformulations, the reformulation had either positive, zero or very moderate negative effects on the sales value of the product category to which the reformulated product belonged.

Conclusions: Based on these findings, 'silent' reformulation of retailer's private brands towards lower energy density seems to contribute to lowering the calorie intake in the population (although to a moderate extent) with moderate losses in retailer's sales revenues.

Keywords: Health promotion, Food product reformulation, Consumer demand

\section{Background}

Food product reformulation is seen as one among several tools to promote healthier eating [1-3]. By reformulating the recipe for a processed food, e.g. reducing the fat, sugar or salt content of the foods, or increasing the content of whole-grains, food manufacturers can help consumers pursue a healthier life style, even without changing their dietary behavior.

The research literature on food product reformulation aiming at health improvements has considered the size of

\footnotetext{
* Correspondence: jorgen@ifro.ku.dk

'University of Copenhagen, Department of Food and Resource Economics,

Rolighedsvej 25, 1958 Frederiksberg C, Denmark

Full list of author information is available at the end of the article
}

the potentials for health promotion via product reformulation, the industry's economic incentives to reformulate, or the possible barriers for such reformulation to occur. Regarding health promotion potentials, a number of studies have considered reduction of salt content $[4,5]$, replacement of trans-fatty acids (TFA) [6, 7] in food products, or enhancement of whole-grain from foods [8]. Often, such studies use a static approach ignoring any behavioural adjustments to the reformulation among the consumers, and thus find that such product reformulations are promoting public health.

Studies addressing food producers' incentives to undertake product reformulation tend to fall in one of two categories [9]: supply-side incentives to reformulate driven 
by costs of ingredients - which in turn may be driven by e.g. agricultural policy - and demand-side incentives driven by the possibility to reap competitive advantages from consumers' demand for healthier products $[10,11]$. Downs et al. [3] reviewed the literature on the effectiveness of policies to reduce the intake of TFA, such as bans or labelling. Regarding TFA in food, most of the reviewed studies found that policy interventions had led to reformulation of products to contain less TFA. The topic was also studied by Unnevehr \& Jagmanaite [10] with a particular focus on stimulus to reformulate food products towards less content of TFA. Golan \& Unnevehr [9] considered how food industry's incentives to undertake product reformulation may be affected by agricultural policy affecting food manufacturers' input costs. Marotta et al. [11] examined the role of product reformulation for the food industry and whether this strategy can help companies to gain a competitive advantage. They found that improved consumer information is necessary in order for such mechanisms to be effective.

As an alternative to promote reformulated products via information about their healthiness, another product reformulation strategy is to make it 'silent,' i.e. not to announce the reformulation explicitly to the consumers (except on standard nutrition labels). This strategy does not have the potential competitive advantage of appealing to health-oriented consumers for the individual product. Instead, the manufacturer's or retailer's motivation to undertake such silent reformulation could be to enhance the health profile of its corporate brand, considering the reformulation as a part of its Corporate Social Responsibility (CSR) strategy. This type of reformulation strategy seems to have attracted rather little interest in the research literature, even though considerable research interest has been devoted to the potential roles of food industry selfregulation in halting the worldwide increasing trend in overweight, obesity and co-morbidities [12].

The research literature has also devoted relatively little attention to the consumers' adaptation to reformulation of food products and hence its effectiveness in reducing the consumers' intake of calories. Food reformulation towards lower fat, sugar or salt content might induce compensation effects - that the consumers perceive a need (or allowance) to compensate for the reduced contents of such substances by increasing their consumption of other products with these substances. Product reformulation might be expected to change the perceived quality of the products - and hence to affect the comparison between the reformulated product and its substitutes, for example because the reformulated product is considered to be 'unnatural' or a 'diet' product. To the extent that consumers respond to such perceived quality changes, these responses may enhance or undermine the effectiveness.

In the present analysis, consumers are assumed to make their consumption decisions regarding a product, based on their perception of the product's attributes (taste, healthiness, price,...) relative to those in potential substitute products within the same product category, but probably with slightly different characteristics. If a reformulation enhances the perception of one attribute without deteriorating other attributes, the reformulation would be expected to induce an increase in the consumption of that product. On the other hand, if the reformulation leads to a perceived improvement in some attributes but a perceived negative effect on other attributes, the sign of the demand response needs to be based on empirical analysis. It is hypothesized that such substitution effects influence the impact of the product reformulation on consumers' calorie consumption, as well as the retailer's sales value. The key research questions are, whether such substitution effects are significant and whether they are supportive of public health goals and of industry's incentive to undertake such reformulation.

We evaluate the effects of a 'silent' reformulation strategy, namely to reformulate a retail chain's private-label brands to a lower energy density without announcing the reformulation to the consumers. Such a strategy has been exercised by one of the major retail chains in Denmark. The modest changes in the food composition pursuant of the reformulation only had impact on the nutrient content, no impact on price, whilst no or insignificant changes in the sensory quality of the products. Nutrition fact labels on the products were updated as a consequence of the reformulation. If consumers have not noticed changes on the nutrition facts label nor in sensory characteristics, their product choices are hypothesized to be unaffected by the reformulation. On the other hand, if the consumers perceive a change in sensory characteristics or have noticed a changed in nutritional characteristics, their choices could be affected. The direction of such changes is however indeterminate, a priori.

We focus on the consumers' adaptation to such reformulation in eight food product categories in terms of possible changes in their composition of purchases within these categories, based on sales data from a Danish retail chain.

\section{Methods}

\section{Study design and data}

In relation to an epidemiological terminology, the study design can be characterised as an ecological design [13], where the development over time in aggregate sales of individual products is seeked explained by the development in relevant explanatory variables, such as prices and timing of product reformulation.

The dataset for the analysis consists of detailed weekly sales data from one of the larger food retail chains in Denmark for a 52-week period, from the beginning of 
March 2013 till the end of February 2014. The sales data have been enriched by information about energy content in all products $(\mathrm{kcal} / 100 \mathrm{~g}$ or $\mathrm{kcal} / 100 \mathrm{ml})$.

Data concerning product reformulation for eight products were also supplied by the retail chain, including the date (week number), the character of the reformulation and its effect on the product's energy content.

\section{Theoretical assumptions and functional form}

For the empirical analysis of each product category, we have chosen the linearized Almost Ideal Demand (AID) functional specification [14]. The AID model implies that commodity $i$ 's share $w_{i}$ of the product category sales value can be specified as a linear function of the logarithmic prices $p$ and the real budget for the product category $y / P$ (where $P$ is the composite price index of all prices in the product category, calculated according to the Stone price index formula, $\ln P=\sum_{i} w_{i t} \cdot \ln p_{i t}$ ).

In order to investigate the potential effects of product reformulation, we have augmented the AID model with a dummy variable $D$, which assumes the value zero before the reformulation, and the value one after the reformulation, hence

$$
w_{i t}=\alpha_{i}+\sum_{j} \alpha_{i j} \cdot \ln p_{j t}+\beta_{i y} \cdot \ln \left(y_{t} / P_{t}\right)+\gamma_{i} \cdot D_{t}+\varepsilon_{i t}, i=\{1, \ldots, n\}
$$

A linear trend variable and a dummy variable representing the Christmas season (all weeks in December), were included to account for trend and seasonality effects (although the products in the study are not suspected to be subject to strong seasonal variation). Furthermore, in order to adjust for first-order autocorrelation, an autoregressive AR (1) term was included in the estimation.

Adding-up yields $\sum_{i} \alpha_{i}=1, \sum_{i} \alpha_{i j}=0, \sum_{i} \beta_{y i}=0, \sum_{i} \gamma_{i}=0$, given that the budget shares sum to one. At the individual consumer level, a theoretically consistent demand model should also fulfil properties of linear homogeneity and Slutsky symmetry. However, as the retailer sales data used in this study can be considered as an aggregate of several consumers, these assumptions cannot be expected to hold, and have therefore not been imposed on the econometric estimation.

Based on econometric estimation of the AID model, it is possible to separate out the effect of the reformulation dummy on the composition of product purchases at a given budget as $\left.\Delta x_{i t}\right|_{\Delta D}=\gamma \cdot y_{t} / p_{i t}$. This effect reflects possible indirect within-commodity-group substitution behaviour triggered by the reformulation. The substitution effect influences both the turnover of calories and the total sales value, within the respective product categories. Other effects, such as effects of price changes, overall sales volume changes or trend development could also be separated out, but this is outside the scope of this paper and is not presented.
In addition to the indirect substitution effects of the reformulation on calorie turnover, there is also a direct effect of product reformation in terms of changed energy density of the reformulated products, $\Delta k_{i}$. Hence, total effect of the reformulation on calorie turnover can be determined as

$$
\left.\Delta K\right|_{\text {reformulation }}=\sum_{i} x_{i t} \cdot \Delta k_{i}+\left.\sum_{i} k_{i} \cdot \Delta x_{i t}\right|_{\Delta D}
$$

For sales value, the effect of the reformulation is given by:

$$
\Delta R=\left.\sum_{i} p_{i} \cdot \Delta x_{i t}\right|_{\Delta D}
$$

\section{Products}

Within the considered data period, the retail chain reformulated nine of their private label food products with the aim to lower their energy content. The nine products and their reformulations are displayed in Table 1 . Two of the product reformulations were implemented simultaneously in two close substitute products (orange-flavoured yoghurt and peach melba-flavoured yoghurt), and in the subsequent analysis, this double-reformulation is analysed as one combined setting.

As appears from the table, the extent of reformulation in terms of reduction in energy density has varied across the different products. For example, for mayonnaise and fruit-flavoured yoghurt, the calorie content was reduced by $16-17 \%$, whereas for bread products the reduction was $5-10 \%$, and for chocolate-flavoured muesli only $2-3 \%$.

Most of the affected product categories can be considered as 'high-frequency buys', where the possible demand effects of a reformulation would be measureable within few weeks after the reformulation has been implemented. One exception may be mayonnaise, where households' purchase frequency is likely to be lower and where it may take longer to detect an influence of the reformulation. However, as the data for mayonnaise spans more than a half year after the reformulation, we would still expect to be able to measure an effect, if any.

\section{Results}

In the following, results are presented for the eight reformulations, based on econometric estimation of the demand model outlined in the previous section. In Table 2 , the reformulations' effects on calorie turnover and sales value are evaluated for the group of relatively close substitutes, which the product is presumed to belong to. Detailed econometric estimation results for each commodity category are given in Tables $3,4,5,6,7,8$, 9 and 10 in the Appendix. In general, the estimated models displayed satisfactory goodness-of-fit and only little sign of misspecification, such as heteroscedasticity, autocorrelation or non-normality in residuals. 
Table 1 Overview of considered product reformulations and categories

\begin{tabular}{|c|c|c|c|c|c|}
\hline Product & $\begin{array}{l}\text { Change in } \\
\text { energy } \\
\text { density (\%) }\end{array}$ & $\begin{array}{l}\text { Date of } \\
\text { reformulation }\end{array}$ & Category products & $\begin{array}{l}\text { Reformulated } \\
\text { product's share } \\
\text { of category's } \\
\text { calorie turnover }\end{array}$ & $\begin{array}{l}\text { Reformulated product's } \\
\text { share of category's } \\
\text { sales value }\end{array}$ \\
\hline & Kcal/ $100 \mathrm{~g}$ & Week/ year & & Per cent & Per cent \\
\hline Mayonnaise & $720 \rightarrow 600(17)$ & $36 / 2013$ & $\begin{array}{l}\text { Private-label mayonnaise, Private-label light } \\
\text { mayonnaise, Unbranded lemon mayonnaise, } \\
\text { Brand } 1 \text { mayonnaise (tube), Brand } 1 \\
\text { mayonnaise, Brand } 1 \text { lemon mayonnaise }\end{array}$ & 51 & 38 \\
\hline $\begin{array}{l}\text { Fruit yoghurt Orange } \\
\text { Peach melba }\end{array}$ & $\begin{array}{l}93 \rightarrow 77(17) \\
90 \rightarrow 74(18)\end{array}$ & $14 / 2013$ & $\begin{array}{l}\text { Private-label peach melba yoghurt, Private- } \\
\text { label orange yoghurt, Banana/pear yoghurt, } \\
\text { Pineapple/orange/mango yoghurt, Peach/ } \\
\text { passion fruit yoghurt, Berry-flavoured yoghurts, } \\
\text { Low-calorie berry-flavoured yoghurts, }\end{array}$ & 156 & 115 \\
\hline $\begin{array}{l}\text { Pumpkin seed } \\
\text { rye bread }\end{array}$ & $240 \rightarrow 232(3)$ & $22 / 2013$ & $\begin{array}{l}\text { Private-label pumpkin seed rye bread, Private- } \\
\text { label sunflower seed rye bread, Brand } \\
\text { sunflower rye bread, Brand organic sunflower } \\
\text { rye bread }\end{array}$ & 14 & 12 \\
\hline Toasting bun & $280 \rightarrow 270(4)$ & $36 / 2013$ & $\begin{array}{l}\text { Private-label toasting bun, Private-label } \\
\text { whole-grain toasting buns, Brand } \\
\text { toasting bun }\end{array}$ & 64 & 60 \\
\hline Yoghurt bread & $270 \rightarrow 250(7)$ & $32 / 2013$ & $\begin{array}{l}\text { Private-label yoghurt bread, Brand1 wholemilk } \\
\text { bread, Brand1 yoghurt bread, Brand2 wholemilk } \\
\text { bread, Brand } 3 \text { five-grain bread }\end{array}$ & 43 & 38 \\
\hline Carrot buns & $310 \rightarrow 281(9)$ & $22 / 2013$ & $\begin{array}{l}\text { Private-label carrot buns, Brand } 1 \text { carrot buns, } \\
\text { Brand1 other buns, Brand } 2 \text { buns }\end{array}$ & 54 & 46 \\
\hline Whole-grain rolls & $260 \rightarrow 240(8)$ & $22 / 2013$ & $\begin{array}{l}\text { Private-label whole-grain rolls, Brand1 multi- } \\
\text { grain rolls, Brand2 Sandwich rolls, Brand } 2 \\
\text { grain rolls, Brand } 3 \text { Whole-grain rolls }\end{array}$ & 35 & 30 \\
\hline Chocolate muesli & $410 \rightarrow 400(2)$ & $18 / 2013$ & $\begin{array}{l}\text { Private-label chocolate muesli, Private-label regular } \\
\text { muesli, Brand1 chocolate cereals, Brand } 2 \text { chocolate } \\
\text { cereals, Brand } 3 \text { chocolate cereals }\end{array}$ & 21 & 21 \\
\hline
\end{tabular}

Note: Week numbers represent the placement of the week in the calendar year. For instance, week 36 in 2013 spanned the dates September 2-8, 2013

Table 2 Direct and indirect effects of product reformulation on calorie turnover and sales value for product groups (per cent)

\begin{tabular}{|c|c|c|c|c|}
\hline & \multicolumn{3}{|c|}{ 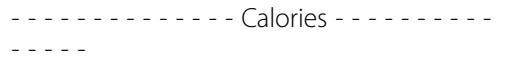 } & \multirow[b]{2}{*}{$\begin{array}{l}\text { Sales } \\
\text { revenue }\end{array}$} \\
\hline & $\begin{array}{l}\text { Direct } \\
\text { reformulation }\end{array}$ & $\begin{array}{l}\text { Reformulation- } \\
\text { induced substitution }\end{array}$ & $\begin{array}{l}\text { Total } \\
\text { calorie }\end{array}$ & \\
\hline Mayonnaise & $-8.2 \%$ & $0.7 \%$ & $-7.5 \%$ & $0.4 \%$ \\
\hline Fruit yoghurt & $-3.9 \%$ & $0.1 \%^{\mathrm{N} . S .}$ & $-3.8 \%$ & $0.1 \%{ }^{\text {N.S. }}$ \\
\hline $\begin{array}{l}\text { Rye bread with } \\
\text { pumpkin seeds }\end{array}$ & $-0.5 \%$ & $0.7 \%$ N.S. & $0.2 \%$ & $0.7 \%$ N.S. \\
\hline Toasting buns & $-2.3 \%$ & $-0.7 \%$ & $-3.0 \%$ & $-0.5 \%$ \\
\hline Yoghurt bread & $-3.2 \%$ & $-0.5 \%$ N.S. & $-3.7 \%$ & $-0.5 \%$ N.S \\
\hline Carrot buns & $-4.9 \%$ & $0.7 \%$ N.S. & $-4.2 \%$ & $0.4 \%$ N.S. \\
\hline $\begin{array}{l}\text { Whole-grain } \\
\text { rolls }\end{array}$ & $-2.7 \%$ & $0.0 \%$ & $-2.7 \%$ & $-0.1 \%$ \\
\hline $\begin{array}{l}\text { Chocolate } \\
\text { muesli }\end{array}$ & $-0.5 \%$ & $3.7 \%$ N.S. & $3.1 \%$ & $2.2 \%$ N.S. \\
\hline
\end{tabular}

N.S. Not significant

\section{Mayonnaise}

The reformulation has led to a partial decrease in calories from the reformulated mayonnaise product by $17 \%$, as indicated in Table 1, which contributes by about $8 \%$ reduction in the total calories from the group of mayonnaise products in this retail chain. The partial substitution effect of the reformulation increased the sale of the reformulated product by $2.6 \%$ (and hence the calories from this variety) at the cost of the private-label light variety, which decreased by $0.5 \%$ due to this substitution (the latter not statistically significant, though). An interpretation of this substitution effect is that consumers tend to prefer the taste of regular mayonnaise to that of light mayonnaise, but they are also concerned about the calories in the mayonnaise. When the calorie content of the regular variety comes closer to that of the light variety, their trade-off between the two varieties becomes more in favour of the regular variety, and they become more prone to choose this variety. In total, the reformulation has led to a $7.5 \%$ reduction in calorie sales in mayonnaise.

The reformulation-induced substitution effects on sales value are identical to those on calorie turnover for the 
individual products. However, because effects on turnover are weighted by products' turnover shares, and effects on calories are weighted by products' calorie shares, the total percentage reformulation-induced substitution effect differs for the two outcome measures. Hence, the increase in turnover due to the reformulation per se is relatively less than the corresponding contribution to change in calorie sales - but still positive. According to these results, the retailer thus did not lose revenue due to the reformulation of the private-label mayonnaise.

\section{Fruit yoghurt}

The two reformulated yoghurts represent $11-15$ and 5-6\% of total fruit yoghurt sales, respectively, and neither of them could be considered as dominating in terms of sales. The direct reformulation effect constituted around 17\% reduction in calorie content for both reformulated product types. Taking into account that these two products represent around $20 \%$ of total calorie sales, this direct effect amounts to $3.9 \%$ of total calorie turnover from the fruit yoghurts. The reformulation-induced substitution effects were not statistically significant, and the results in Table 2 also indicates very small contributions to the change in calorie turnover and sales value from this effect.

\section{Rye bread with pumpkin seeds}

One private-label variety of rye bread with pumpkin seeds was reformulated to contain fewer sunflower seeds and more pumpkin seeds and wholegrain rye, thus reducing the calories from 240 to 232 per $100 \mathrm{~g}$. For the rye bread reformulation, the direct reformulation effect led to a $3.3 \%$ reduction in the reformulated bread, which implied a $0.5 \%$ partial reduction in the total calories from this product category. Reformulation-induced substitution effects led to a (not statistically significant) $0.7 \%$ increase in the calorie turnover - and in sales revenue. The net effect of the reformulation on calorie turnover was an insignificant $0.2(=0.7-0.5)$ per cent increase, and the partial effect of the reformulation on sales value was an (insignificant) increase of $0.7 \%$. Hence, the reduction in calorie turnover due to the reformulation could be done without reducing the sales value of this group of rye bread.

\section{Toasting buns}

One private-label 'normal' toasting bun ("krydderboller" in Danish) was reformulated to contain less fat and sugar, thus reducing the calorie content from 280 to $270 \mathrm{kcal}$ per $100 \mathrm{~g}$. The direct effect of the reformulation was a reduction of $3.6 \%$ calorie content in the reformulated product - which impacted the average calorie turnover in toasting buns by $2.3 \%$. Reformulationinduced substitution effects implied a (weakly significant) shift from the reformulated private-label product to the whole-grain private-label variety, implying a net reduction in calorie turnover of $0.7 \%$. Hence, the reformulation implied a $3 \%$ reduction in calorie turnover from toasting buns. The substitution effect also implied a reduction in sales revenue of $0.5 \%$ from these buns.

\section{Yoghurt bread}

In the category of light bread, the retailer's private label yoghurt bread was reformulated to contain more rye flour and less fat, which reduced the calorie content from 270 to $250 \mathrm{kcal} / 100 \mathrm{~g}$. The direct effect of the reformulation was a $7.4 \%$ reduction in the calorie content of the reformulated product, and thus to a $3.2 \%$ reduction for the product category as a whole. Substitution effects induced by the reformulation led to (insignificant) decrease in the sale of the reformulated product and slight increases in some of the other products, leading to an overall $0.5 \%$ reduction in calorie sales, and a corresponding effect on sales value.

\section{Buns with carrot}

Private-label buns with carrot were reformulated to contain less sunflower seeds, more durum seeds, more carrot and no eggs. The direct effect of the reformulation was a reduction of the calorie content in these buns with $9.4 \%$ - and as these buns constitute about half of the considered product category, this implied a direct effect on the calorie turnover of this product category by $4.9 \%$. Although statistically insignificant, the reformulation-induced substitution effects led to an increased sale of the reformulated buns, at the cost of another variety, and the net effect of this substitution was an increase of $0.7 \%$ in calorie turnover. Hence, the reformulation yielded a $4.2 \%$ reduction in calorie turnover, and a $0.4 \%$ increase in sales value of the buns within this product category.

\section{Whole grain breakfast rolls}

Private-label whole-grain rolls were reformulated to contain less oil, which reduced the energy density from 260 to $240 \mathrm{kcal} / 100 \mathrm{~g}$. It may not be completely evident, which products are likely to be close substitutes to these rolls - and especially if this would be other types of rolls for lunch sandwiches, or other types of rolls on the breakfast table. In the case of breakfast use, the sales data contain very little substitute products within the fresh bread category, and hence the product reformulation could be expected to induce relatively little substitution in the sales, and the direct reformulation effect (i.e. a $7.7 \%$ reduction in calorie turnover from the category) would be the dominating effect.

On the other hand, if other types of sandwich rolls could substitute the reformulated rolls, we consider six 
products as close substitutes. The direct effect of the reformulation on the reformulated product was an $8 \%$ reduction in the calorie content. As the reformulated product represented around one third of the total sales within this category, this implies a reduction of $2.7 \%$ in the product category. Reformulation-induced substitution effects implied some shifts in the composition of this product category - however with a zero effect on total calorie turnover. Although this substitution effect was relatively small on the reformulated product, it seems to have induced a shift between some of the other product varieties. The reformulation-induced substitution effects implied a $0.1 \%$ reduction in the sales value from this product category. These somewhat peculiar substitution effects may have to do with the above considerations about which products are the actual substitutes for the reformulated whole grain rolls.

\section{Chocolate muesli}

The retailer has reformulated its private-label chocolate muesli product to contain more grains (wheat and oats) and less salt, and reduce the energy density from 410 to $400 \mathrm{kcal} / 100 \mathrm{~g}$. The direct effect of the reformulation was a $2.4 \%$ reduction in calorie content of the reformulated chocolate muesli. As this product constituted around $20 \%$ of the product category, this meant a reduction in the calories from this category of $0.5 \%$. The substitution effects of the reformulation implied an (insignificant) increase in the sales of the private-label regular muesli products, at the cost of especially one of the other brands. This substitution effect led to a $3.7 \%$ increase in calorie sales, from the product category, and hence a net increase of $3.1 \%$ in calorie turnover. The reformulation-induced substitution effect on sales value was an increase of $2.2 \%$.

\section{Discussion}

For all products, the direct effect of product reformulation was a reduction in the sale of calories from the respective product categories. In several of the cases, the reformulation led to indirect substitution effects that to some extent were counterproductive with regard to reducing calorie turnover - but in all cases except for chocolate muesli and rye-bread, these indirect substitution effects were dominated by the direct effect of the reformulation. For all considered product reformulations, except that of toasting buns, the reformulation had either positive, zero or very moderate negative effects on the sales value of the product category to which the reformulated product belonged. Consequently, the examples suggest that silent product reformulation can be a somewhat effective and economically feasible strategy for retailers to reduce their customers' consumption of calories from their products.
It is worth noting that in most of the considered cases, the modelled reformulation did not have statistically significant effects on the composition of consumption within the respective product categories. Hence, 'silent' product reformulation does not seem to scare consumers away, nor attract new consumers. Mayonnaise is an exception from this general pattern, as the reformulation seems to have increased the demand for the reformulated private-label product, mainly at the cost of the 'light' private-label product.

Buttriss [14] pointed at some of the challenges that may have to be met in relation to food product reformulation to a lower fat or sugar content. One challenge is the constraints of food legislation for some sectors, such as minimum requirements to the fat content of e.g. a chocolate product to be marketed as such, or regulation of nutrition and health claims, which may constrain producers' publicising changes in fat content. In addition, the Danish legislation on food labelling requires that a food product to be labelled as 'light' or 'low-fat' should have an energy content of maximum $70 \%$ of the corresponding 'regular' product, which may also limit the scope and incentive for reformulation.

Another challenge is that manufacturers have an interest to retain the characteristics of the product that are attractive to consumers, making reformulation to reduce fat a costly and time-consuming exercise. Reducing sugar content also poses challenges because sugar's role in foods is often more than simply providing sweetness, and different alternative approaches may be needed to provide the products with these attributes. Some of these alternative approaches have limitations, due to e.g. regulatory constraints, potential gastrointestinal consequences associated with some alternative ingredients, consumers' resistance to foods containing many additives, or that the alternatives are often more costly than sugar.

The product reformulations considered in this study have been quite moderate, as also mentioned above. Previous studies [15-17] indeed suggest that gradual product reformations, with fairly small steps at the time and thus slowly familiarizing the consumers with changes in taste and other characteristics, can be a fruitful strategy for health-promoting product reformulations. Due to the rather moderate extent of the considered reformulations, the magnitude of the public health impact might also be limited. Nevertheless, the results of the analysis provide fairly clear indications of a reduction in calorie intake in the respective commodity groups.

\section{Limitations of the study}

In the empirical analysis, we have adopted the assumption of a "representative consumer" purchasing the range 
of products in the considered retail chain, and we have estimated behavioural parameters reflecting utility maximization behaviour of this representative consumer. This assumption implies that the composition of consumers - and hence the average preferences - is assumed to be stable throughout the 52-weeks data period, or develops along a linear trend.

Furthermore, we have assumed weak separability in consumption in the sense that the composition of specific products within a certain (narrow) product category (e.g. the mayonnaise category or chocolateflavoured breakfast cereals category) is independent of the relative prices of products outside this product category [18]. This assumption has enabled us to estimate separate systems of demand equations within each product category. But the separability structure also imposes restrictions on the substitution patterns that can be detected by the analysis. In the analysis, we have considered substitution effects between the reformulated product and its close substitutes. In most cases, the range of close substitutes was relatively straightforward. However, for some of the bread products, some subjective judgement as to which products were 'close' substitutes, and which were 'less close' substitutes, was necessary. Although the delimitation of these product categories was done to the best of the authors' capabilities, this may induce some uncertainty to the results for these products.

The product reformulation was represented as a 'dummy' (or binary) variable in the econometric analysis. This approach implies the assumption that from the date of reformulation, the consumers can only buy the reformulated version of the product - and not the 'old' version. For products with a shelf life of about 1 week (such as fruit yoghurt or fresh bread), this is not an unrealistic assumption. But for chocolate muesli and mayonnaise, there may have been a longer transition period, where the individual stores have emptied their shelves with the 'old' version, before they introduced the reformulated version of the product, and this may have introduced uncertainty to the results for these two products.

The 'dummy' variable representation also assumes that the consumers either consider the reformulation in their purchase decision from day one - or do not consider it at all. Again, this may introduce some uncertainty to the results.

The econometric estimation assumes stability in the population of consumers and its composition - or as a minimum that any development in this composition can be captured by the linear trend variable included in the estimation equations. The considered retail chain has however expanded quite significantly during the 52 weeks of consideration. For this reason, this assumption could be questioned - especially if new stores have been established in areas with 'new' socio-demographic characteristics, compared to those of the 'old' stores.

The analysis is based on sales data from only this one retail chain. Thus, interpreting the results as representative for the population of consumers has to be based on an assumption that their choice of store has not been affected by the product reformulation. It might be hypothesized that changes (e.g. assortment changes, price changes, product reformulations) could induce substitution effects in the consumers' choice of store. Address of such effect across stores is however very difficult and has not been possible in this study. It might be presumed that such substitution effects would undermine the possible health promoting effects, because consumers seek 'un-reformulated' products in other stores. On the other hand, the reformulation may also attract new customers. However, as the considered reformulations are generally quite moderate, and because the chain's stores already have fairly broad assortments of relevant substitutes, such across-store substitution effects are considered to be negligible. Although this may appear a realistic assumption, it has not been verified in this study, and this may also add to the uncertainty of the results.

\section{Conclusion}

This study has evaluated the effects of 'silent' reformulating a retail chain's private-label brands to a lower energy density, based on weekly sales data for a period of 52 weeks from a Danish retail chain. The analysis distinguishes between the direct effect of the lower energy density in the reformulated product and the indirect effects due to reformulation-induced product substitution. For seven out of the eight reformulated products considered in the study, the reformulation led to a reduction in calorie sales (defined as the sum of the direct and indirect effects from the reformulation). For chocolate muesli, a counter-productive (but statistically insignificant) substitution effect outweighed the direct effect of the reformulation. In most cases, the estimated reformulation-induced substitution effects were small and statistically insignificant. Hence, the sales value was only affected to a little extent - and only negatively affected in two of the eight cases considered.

Based on these findings, 'silent' reformulation of retailer's private brands towards lower energy density, seems to be a promising strategy for the retail sector to contribute to lower calorie intake in the population, and thus supportive of public health goals and industry's incentive to undertake also modest and silent reformulations. 


\section{Appendix}

Table 3 Detailed results for mayonnaise

\begin{tabular}{|c|c|c|c|c|c|}
\hline & Brand 1, tube & Private label light & Private label & Unbranded lemon & Brand 1, lemon \\
\hline Initial share of calories & $6.2 \%$ & $12.2 \%$ & $50.9 \%$ & $0.3 \%$ & $1.9 \%$ \\
\hline Initial share of sales value & $13.7 \%$ & $16.1 \%$ & $37.6 \%$ & $0.5 \%$ & $1.8 \%$ \\
\hline \multicolumn{6}{|l|}{ AID model estimation results } \\
\hline \multirow[t]{2}{*}{ Ln $P_{\text {Brand } 1 \text {, tube }}$} & 0.1937 & 0.1072 & 0.5578 & -0.0047 & -0.0776 \\
\hline & $(0.1669)$ & $(0.2123)$ & $(0.3727)$ & $(0.0430)$ & $(0.1428)$ \\
\hline \multirow[t]{2}{*}{ Ln P Private label light } & -0.1631 & -0.3367 & -0.5005 & -0.0184 & -0.1574 \\
\hline & $(0.2208)$ & $(0.3015)$ & $(0.5126)$ & $(0.0660)$ & $(0.2053)$ \\
\hline \multirow[t]{2}{*}{ Ln P Private label } & -0.0469 & -0.0145 & 0.3002 & 0.0288 & -0.0221 \\
\hline & $(0.0529)$ & $(0.0795)$ & $(0.1248)$ & $(0.0175)$ & $(0.0536)$ \\
\hline \multirow[t]{2}{*}{ Ln Punbranded lemon } & 0.0009 & -0.0060 & -0.0398 & 0.0094 & 0.0056 \\
\hline & $(0.0168)$ & $(0.0200)$ & $(0.0361)$ & $(0.0038)$ & $(0.0125)$ \\
\hline \multirow[t]{2}{*}{ Ln P Prand 1} & 0.0600 & 0.0515 & 0.1887 & 0.0026 & -0.0214 \\
\hline & $(0.0063)$ & $(0.0064)$ & $(0.0128)$ & $(0.0013)$ & $(0.0040)$ \\
\hline \multirow[t]{2}{*}{ Ln $P_{\text {Brand }} 1$ lemon } & 0.0043 & -0.0012 & 0.0187 & -0.0001 & 0.0066 \\
\hline & $(0.0124)$ & $(0.0152)$ & $(0.0274)$ & $(0.0031)$ & (0.0098) \\
\hline \multirow[t]{2}{*}{ Real budget } & 0.0111 & -0.0139 & -0.0204 & 0.0013 & 0.0027 \\
\hline & $(0.0056)$ & $(0.0062)$ & $(0.0117)$ & $(0.0012)$ & $(0.0039)$ \\
\hline \multirow[t]{2}{*}{ Reformulation dummy } & 0.0107 & -0.0045 & 0.0260 & -0.0009 & -0.0094 \\
\hline & $(0.0040)$ & $(0.0067)$ & (0.0098) & $(0.0016)$ & $(0.0047)$ \\
\hline \multirow[t]{2}{*}{ a10 } & 0.1123 & 0.0207 & 0.1091 & 0.0058 & -0.0227 \\
\hline & $(0.0412)$ & $(0.0513)$ & (0.0913) & $(0.0103)$ & $(0.0343)$ \\
\hline \multirow[t]{2}{*}{ Trend } & -0.0005 & -0.0004 & 0.0000 & 0.0000 & -0.0001 \\
\hline & $(0.0003)$ & $(0.0005)$ & $(0.0007)$ & $(0.0001)$ & $(0.0003)$ \\
\hline \multirow[t]{2}{*}{ Christmas dummy } & -0.0025 & -0.0021 & -0.0117 & 0.0007 & 0.0093 \\
\hline & $(0.0049)$ & $(0.0070)$ & (0.0115) & (0.0015) & $(0.0047)$ \\
\hline \multirow[t]{2}{*}{ AR (1) } & -0.0083 & 0.5079 & 0.2058 & 0.7861 & 0.6214 \\
\hline & $(0.1816)$ & $(0.1553)$ & $(0.1785)$ & $(0.1212)$ & (0.1336) \\
\hline \multirow[t]{2}{*}{ Intercept } & -0.1459 & 0.6999 & -0.6859 & -0.0436 & 0.5860 \\
\hline & $(0.2842)$ & $(0.4293)$ & $(0.6790)$ & $(0.1042)$ & $(0.2956)$ \\
\hline Root MSE & 0.0056 & 0.0067 & 0.0121 & 0.0014 & 0.0043 \\
\hline$R^{2}$ & 0.90 & 0.85 & 0.94 & 0.84 & 0.83 \\
\hline$R^{2}$-adj & 0.86 & 0.80 & 0.92 & 0.78 & 0.78 \\
\hline
\end{tabular}


Table 4 Detailed results, fruit yoghurt

\begin{tabular}{|c|c|c|c|c|c|}
\hline & Private label peach melba & Private label orange & Pear/ banana & Pineapple/ orange/ mango Light & Berry-flavoured \\
\hline Initial share of calories & $15.4 \%$ & $5.8 \%$ & $44.9 \%$ & $4.0 \%$ & $21.4 \%$ \\
\hline Initial share of sales value & $11.4 \%$ & $5.3 \%$ & $37.1 \%$ & $8.9 \%$ & $20.3 \%$ \\
\hline \multicolumn{6}{|l|}{ AID model estimation results } \\
\hline \multirow[t]{2}{*}{ Ln P Private label peach melba } & 0.000006 & 0.000002 & -0.000004 & -0.000001 & -0.000002 \\
\hline & $(0.000001)$ & $(0.000000)$ & $(0.000001)$ & $(0.000001)$ & $(0.000001)$ \\
\hline \multirow[t]{2}{*}{ Ln P Private label orange } & 0.000001 & 0.000002 & 0.000000 & 0.000001 & -0.000004 \\
\hline & $(0.000001)$ & $(0.000001)$ & $(0.000001)$ & $(0.000001)$ & $(0.000002)$ \\
\hline \multirow[t]{2}{*}{ Ln P Pear/banana } & 0.000005 & 0.000006 & 0.000004 & -0.000006 & 0.000002 \\
\hline & $(0.000002)$ & $(0.000001)$ & $(0.000003)$ & $(0.000002)$ & $(0.000003)$ \\
\hline \multirow[t]{2}{*}{ Ln P Pineapple/orange/mango Light } & 0.000001 & 0.000001 & -0.000005 & 0.000015 & -0.000002 \\
\hline & $(0.000001)$ & $(0.000001)$ & $(0.000001)$ & $(0.000001)$ & $(0.000001)$ \\
\hline \multirow[t]{2}{*}{ Ln $P_{\text {Berry }}$} & -0.000001 & 0.000001 & -0.000006 & -0.000001 & 0.000021 \\
\hline & $(0.000002)$ & $(0.000001)$ & $(0.000002)$ & $(0.000003)$ & $(0.000003)$ \\
\hline \multirow[t]{2}{*}{ Ln $P_{\text {Berry Light }}$} & -0.000002 & 0.000000 & -0.000010 & -0.000002 & -0.000006 \\
\hline & $(0.000001)$ & $(0.000001)$ & $(0.000001)$ & $(0.000001)$ & $(0.000002)$ \\
\hline \multirow[t]{2}{*}{ Real budget } & 0.000011 & 0.000013 & -0.000010 & -0.000005 & 0.000009 \\
\hline & $(0.000004)$ & $(0.000003)$ & $(0.000005)$ & $(0.000004)$ & $(0.000005)$ \\
\hline \multirow[t]{2}{*}{ Reformulation dummy } & -0.004530 & 0.000008 & 0.002339 & -0.000570 & 0.005419 \\
\hline & $(0.003120)$ & (0.002320) & $(0.004070)$ & $(0.006260)$ & $(0.008760)$ \\
\hline \multirow[t]{2}{*}{ Trend } & -0.000150 & 0.000004 & -0.000130 & -0.000920 & 0.001534 \\
\hline & $(0.000056)$ & $(0.000041)$ & $(0.000073)$ & $(0.000577)$ & $(0.000626)$ \\
\hline \multirow[t]{2}{*}{ Christmas dummy } & -0.001470 & 0.000176 & -0.006100 & -0.000950 & 0.005525 \\
\hline & $(0.002460)$ & $(0.001760)$ & $(0.003190)$ & $(0.004400)$ & $(0.006080)$ \\
\hline \multirow[t]{2}{*}{ AR (1) } & -0.402090 & -0.186420 & -0.263600 & 0.879930 & 0.862313 \\
\hline & $(0.147000)$ & $(0.181400)$ & $(0.174500)$ & $(0.093100)$ & $(0.080600)$ \\
\hline \multirow[t]{2}{*}{ Intercept } & 0.095738 & 0.048126 & 0.362423 & 0.113309 & 0.161103 \\
\hline & $(0.006660)$ & $(0.004570)$ & $(0.008380)$ & $(0.023100)$ & $(0.026200)$ \\
\hline Root MSE & 0.0044 & 0.0028 & 0.0053 & 0.0055 & 0.0076 \\
\hline$R^{2}$ & 0.91 & 0.83 & 0.96 & 0.95 & 0.93 \\
\hline$R^{2}$-adj & 0.89 & 0.78 & 0.95 & 0.93 & 0.91 \\
\hline
\end{tabular}


Table 5 Detailed results - rye bread with pumpkin seeds

\begin{tabular}{|c|c|c|c|}
\hline & $\begin{array}{l}\text { Private label } \\
\text { pumpkin }\end{array}$ & $\begin{array}{l}\text { Private label } \\
\text { sunflower }\end{array}$ & $\begin{array}{l}\text { Brand organic } \\
\text { sunflower }\end{array}$ \\
\hline Initial share of calories & $13.8 \%$ & $12.0 \%$ & $0.0 \%$ \\
\hline Initial share of sales value & $11.8 \%$ & $10.4 \%$ & $0.0 \%$ \\
\hline \multicolumn{4}{|l|}{$\begin{array}{l}\text { AID model estimation } \\
\text { results }\end{array}$} \\
\hline \multirow[t]{2}{*}{ InP Private label pumpkin } & 0.0000 & 0.0000 & 0.0000 \\
\hline & $(0.0000)$ & $(0.0000)$ & $(0.0000)$ \\
\hline \multirow[t]{2}{*}{ InP Private label sunflower } & 0.0000 & 0.0000 & 0.0000 \\
\hline & $(0.0000)$ & $(0.0000)$ & $(0.0000)$ \\
\hline \multirow[t]{2}{*}{ InP $\mathrm{P}_{\text {Brand organic sunflower }}$} & 0.0000 & 0.0000 & 0.0000 \\
\hline & $(0.0000)$ & $(0.0000)$ & $(0.0000)$ \\
\hline \multirow[t]{2}{*}{ InP $P_{\text {Brand other sunflower }}$} & 0.0000 & 0.0000 & 0.0000 \\
\hline & $(0.0000)$ & $(0.0000)$ & $(0.0000)$ \\
\hline \multirow[t]{2}{*}{ Real budget } & 0.0000 & 0.0000 & 0.0000 \\
\hline & $(0.0000)$ & $(0.0000)$ & $(0.0000)$ \\
\hline \multirow[t]{2}{*}{ Reformulation dummy } & -0.0041 & -0.0048 & -0.0015 \\
\hline & $(0.0054)$ & $(0.0049)$ & $(0.0034)$ \\
\hline \multirow[t]{2}{*}{ Trend } & -0.0002 & -0.0002 & 0.0001 \\
\hline & $(0.0002)$ & $(0.0002)$ & $(0.0001)$ \\
\hline \multirow[t]{2}{*}{ Christmas dummy } & -0.0003 & 0.0001 & 0.0006 \\
\hline & $(0.0033)$ & $(0.0031)$ & $(0.0021)$ \\
\hline \multirow[t]{2}{*}{ AR (1) } & -0.1108 & -0.0573 & -0.3948 \\
\hline & $(0.2253)$ & $(0.2215)$ & $(0.2373)$ \\
\hline \multirow[t]{2}{*}{ Intercept } & 0.0942 & 0.0894 & 0.0251 \\
\hline & $(0.0075)$ & $(0.0068)$ & $(0.0051)$ \\
\hline Root MSE & 0.0057 & 0.0051 & 0.0041 \\
\hline$R^{2}$ & 0.99 & 0.99 & 0.97 \\
\hline$R^{2}$-adj & 0.99 & 0.99 & 0.96 \\
\hline
\end{tabular}

Table 6 Detailed results - Toasting buns

\begin{tabular}{|c|c|c|}
\hline & Private-label whole grain & Private-label \\
\hline Initial share of calories & $35.6 \%$ & $0.1 \%$ \\
\hline Initial share of sales value & $39.9 \%$ & $0.1 \%$ \\
\hline \multicolumn{3}{|l|}{ AID model estimation results } \\
\hline \multirow[t]{2}{*}{ Ln P Private-label whole grain } & -0.2273 & 0.2328 \\
\hline & $(0.0501)$ & $(0.0514)$ \\
\hline \multirow[t]{2}{*}{ Ln $P_{\text {Brand }}$} & 0.0008 & -0.0013 \\
\hline & $(0.0043)$ & $(0.0044)$ \\
\hline \multirow[t]{2}{*}{ Ln P Private-label } & 0.0345 & 0.0110 \\
\hline & (0.1968) & $(0.2015)$ \\
\hline \multirow[t]{2}{*}{ Real budget } & 0.1398 & -0.1372 \\
\hline & $(0.0185)$ & $(0.0189)$ \\
\hline \multirow[t]{2}{*}{ Reformulation dummy } & 0.0245 & -0.0246 \\
\hline & $(0.0127)$ & $(0.0130)$ \\
\hline \multirow[t]{2}{*}{ Trend } & 0.0006 & -0.0006 \\
\hline & $(0.0004)$ & $(0.0004)$ \\
\hline \multirow[t]{2}{*}{ Christmas dummy } & -0.0284 & 0.0285 \\
\hline & $(0.0144)$ & $(0.0147)$ \\
\hline \multirow[t]{2}{*}{ AR (1) } & -0.1913 & -0.1923 \\
\hline & $(0.1700)$ & $(0.1699)$ \\
\hline \multirow[t]{2}{*}{ Intercept } & -0.6575 & 1.5197 \\
\hline & $(0.5805)$ & $(0.5942)$ \\
\hline Root MSE & 0.0256 & 0.0262 \\
\hline$R^{2}$ & 0.83 & 0.83 \\
\hline$R^{2}$-adj & 0.80 & 0.79 \\
\hline
\end{tabular}


Table 7 Detailed results - yoghurt bread

\begin{tabular}{|c|c|c|c|c|c|c|c|c|}
\hline & $\begin{array}{l}\text { Brand } 2 \\
\text { Wholemilk }\end{array}$ & $\begin{array}{l}\text { Brand } 1 \\
\text { Wholemilk }\end{array}$ & $\begin{array}{l}\text { Private label } \\
\text { yoghurt bread }\end{array}$ & $\begin{array}{l}\text { Brand } 1 \\
\text { Yoghurt }\end{array}$ & & $\begin{array}{l}\text { Private label } \\
\text { carrot rolls }\end{array}$ & $\begin{array}{l}\text { Brand } 1 \\
\text { carrot rolls }\end{array}$ & $\begin{array}{l}\text { Brand } 1 \\
\text { whole-grain rolls }\end{array}$ \\
\hline & & & & & \multirow{2}{*}{$\begin{array}{l}\text { Initial share of } \\
\text { calories }\end{array}$} & \multirow[t]{2}{*}{$53.7 \%$} & \multirow[t]{2}{*}{$0.0 \%$} & \multirow[t]{2}{*}{$28.2 \%$} \\
\hline Initial share of calories & $0.0 \%$ & $30.2 \%$ & $43.2 \%$ & $0.0 \%$ & & & & \\
\hline $\begin{array}{l}\text { Initial share of sales } \\
\text { value }\end{array}$ & $0.0 \%$ & $31.8 \%$ & $38.2 \%$ & $0.0 \%$ & $\begin{array}{l}\text { Initial share of } \\
\text { sales value }\end{array}$ & $45.6 \%$ & $0.0 \%$ & $30.0 \%$ \\
\hline $\begin{array}{l}\text { AID model estimation } \\
\text { results }\end{array}$ & & & & & $\begin{array}{l}\text { AID model } \\
\text { estimation results }\end{array}$ & & & \\
\hline \multirow[t]{2}{*}{$\ln P_{\text {Brand }} 2$ Wholemilk bread } & 0.1122 & -0.0442 & -0.0484 & 0.0000 & \multirow[t]{2}{*}{ Ln PPrivate label carrot rolls } & 0.0000 & 0.0000 & 0.0000 \\
\hline & $(0.0330)$ & $(0.0172)$ & $(0.0182)$ & $(0.0001)$ & & $(0.0000)$ & $(0.0000)$ & $(0.0000)$ \\
\hline \multirow{2}{*}{$\begin{array}{l}\text { Ln P Prand } 1 \text { Wholemilk } \\
\text { bread }\end{array}$} & 0.2815 & -0.6210 & 0.2239 & 0.0001 & \multirow[t]{2}{*}{ Ln $\mathrm{P}_{\text {Brand } 1 \text { carrot rolls }}$} & 0.0007 & 0.0000 & 0.0006 \\
\hline & $(0.0825)$ & $(0.0430)$ & $(0.0456)$ & $(0.0003)$ & & $(0.0006)$ & $(0.0000)$ & $(0.0007)$ \\
\hline \multirow{2}{*}{$\begin{array}{l}\text { Ln P Private label yoghurt } \\
\text { bread }\end{array}$} & 0.2191 & 0.5111 & -1.1483 & 0.0005 & \multirow[t]{2}{*}{ Ln $P_{\text {Brand } 1 \text { whole-grain rolls }}$} & 0.0000 & 0.0000 & 0.0000 \\
\hline & $(0.3671)$ & $(0.1913)$ & $(0.2028)$ & $(0.0015)$ & & $(0.0000)$ & $(0.0000)$ & $(0.0000)$ \\
\hline \multirow[t]{2}{*}{ Ln PBrand 1 Yoghurt bread } & -0.0251 & 0.0094 & 0.0058 & 0.0001 & \multirow[t]{2}{*}{ Ln $P_{\text {Brand }} 2$ linseed rolls } & 0.0000 & 0.0000 & 0.0000 \\
\hline & $(0.0181)$ & $(0.0094)$ & $(0.0100)$ & $(0.0001)$ & & $(0.0000)$ & $(0.0000)$ & $(0.0000)$ \\
\hline \multirow[t]{2}{*}{ Ln $P_{\text {Brand 3, 5-grain bread }}$} & 0.0612 & 0.1295 & 0.1951 & 0.0002 & \multirow[t]{2}{*}{ Real budget } & 0.0000 & 0.0000 & 0.0000 \\
\hline & $(0.0574)$ & (0.0299) & $(0.0317)$ & $(0.0002)$ & & $(0.0000)$ & $(0.0000)$ & $(0.0000)$ \\
\hline \multirow[t]{2}{*}{ Real budget } & 0.2060 & -0.0789 & -0.0597 & -0.0002 & \multirow[t]{2}{*}{ Reformulation dummy } & 0.0149 & 0.0000 & 0.0151 \\
\hline & $(0.0488)$ & $(0.0254)$ & $(0.0270)$ & $(0.0002)$ & & $(0.0151)$ & $(0.0000)$ & $(0.0166)$ \\
\hline \multirow[t]{2}{*}{ Reformulation dummy } & -0.0013 & 0.0085 & -0.0100 & 0.0000 & \multirow[t]{2}{*}{ Trend } & -0.0012 & 0.0000 & -0.0006 \\
\hline & $(0.0352)$ & $(0.0183)$ & $(0.0194)$ & $(0.0001)$ & & $(0.0005)$ & $(0.0000)$ & $(0.0005)$ \\
\hline \multirow[t]{2}{*}{ Trend } & 0.0006 & -0.0005 & -0.0001 & 0.0000 & \multirow[t]{2}{*}{ Christmas dummy } & 0.0001 & 0.0001 & 0.0001 \\
\hline & $(0.0013)$ & $(0.0007)$ & $(0.0007)$ & $(0.0000)$ & & $(0.0000)$ & $(0.0000)$ & $(0.0000)$ \\
\hline \multirow[t]{2}{*}{ Christmas dummy } & 0.0085 & -0.0166 & -0.0001 & 0.0002 & \multirow[t]{2}{*}{ Intercept } & 0.3657 & 0.0000 & 0.2998 \\
\hline & $(0.0501)$ & $(0.0261)$ & $(0.0277)$ & $(0.0002)$ & & $(0.0520)$ & $(0.0001)$ & $(0.0572)$ \\
\hline \multirow[t]{2}{*}{ Intercept } & -3.3966 & 1.2240 & 2.3714 & -0.0002 & Root MSE & 0.0172 & 0.0000 & 0.0189 \\
\hline & $(1.2671)$ & $(0.6603)$ & $(0.7001)$ & $(0.0053)$ & $R^{2}$ & 0.99 & 0.98 & 0.98 \\
\hline Root MSE & 0.0603 & 0.0314 & 0.0333 & 0.0003 & $R^{2}$-adj & 0.98 & 0.96 & 0.96 \\
\hline$R^{2}$ & 0.62 & 0.93 & 0.88 & 0.28 & & & & \\
\hline$R^{2}$-adj & 0.53 & 0.92 & 0.85 & 0.11 & & & & \\
\hline
\end{tabular}

Table 8 Detailed results - rolls with carrot

Initial share of $\quad 45.6 \% \quad 0.0 \% \quad 30.0 \%$

AID model

stimation results 
Table 9 AID model estimation results - wholegrain rolls

\begin{tabular}{|c|c|c|c|c|}
\hline & Brand 2 sandwich rolls & Private-label wholegrain rolls & Brand 2 , grain rolls & Brand 1 multi-grain rolls \\
\hline Initial share of calories & $18.1 \%$ & $35.1 \%$ & $19.4 \%$ & $27.4 \%$ \\
\hline Initial share of sales value & $16.1 \%$ & $30.1 \%$ & $20.5 \%$ & $33.2 \%$ \\
\hline \multicolumn{5}{|l|}{ AID model estimation results } \\
\hline \multirow[t]{2}{*}{ Ln $\mathrm{P}_{\text {Brand } 2 \text { sandwich rolls }}$} & 0.00003 & -0.00001 & -0.00001 & -0.00001 \\
\hline & $(0.00000)$ & $(0.00000)$ & $(0.00000)$ & $(0.00000)$ \\
\hline \multirow[t]{2}{*}{ Ln P Private-label wholegrain rolls } & -0.00001 & 0.00002 & -0.00001 & -0.00001 \\
\hline & $(0.00000)$ & $(0.00000)$ & $(0.00000)$ & $(0.00000)$ \\
\hline \multirow[t]{2}{*}{ Ln $\mathrm{P}_{\text {Brand 2, grain rolls }}$} & -0.00001 & -0.00001 & 0.00002 & -0.00001 \\
\hline & $(0.00000)$ & $(0.00000)$ & $(0.00000)$ & $(0.00000)$ \\
\hline \multirow[t]{2}{*}{ Ln $P_{\text {Brand } 1 \text { multi grain rolls }}$} & -0.00001 & -0.00002 & -0.00001 & 0.00004 \\
\hline & $(0.00000)$ & $(0.00000)$ & $(0.00000)$ & $(0.00000)$ \\
\hline \multirow[t]{2}{*}{$\mathrm{LnP}_{\text {Brand }} 3$ wholegrain } & -0.00005 & 0.00008 & 0.00000 & -0.00004 \\
\hline & $(0.00006)$ & $(0.00015)$ & $(0.00010)$ & $(0.00011)$ \\
\hline \multirow[t]{2}{*}{ Real budget } & 0.00000 & -0.00001 & 0.00000 & 0.00001 \\
\hline & $(0.00000)$ & $(0.00000)$ & $(0.00000)$ & $(0.00000)$ \\
\hline \multirow[t]{2}{*}{ Reformulation dummy } & -0.00615 & 0.00408 & 0.01379 & -0.01164 \\
\hline & $(0.00399)$ & (0.00998) & $(0.00683)$ & $(0.00756)$ \\
\hline \multirow[t]{2}{*}{ Trend } & 0.00000 & 0.00008 & -0.00012 & 0.00005 \\
\hline & $(0.00007)$ & $(0.00018)$ & $(0.00012)$ & $(0.00014)$ \\
\hline \multirow[t]{2}{*}{ Christmas dummy } & -0.00056 & 0.00234 & 0.00000 & -0.00206 \\
\hline & $(0.00534)$ & $(0.01330)$ & $(0.00913)$ & $(0.01010)$ \\
\hline \multirow[t]{2}{*}{ AR (1) } & 0.22398 & 0.20410 & 0.38075 & 0.00000 \\
\hline & $(0.02580)$ & $(0.01760)$ & $(0.01950)$ & $(0.00000)$ \\
\hline \multirow[t]{2}{*}{ Intercept } & 0.19093 & 0.22398 & 0.20410 & 0.38075 \\
\hline & $(0.01030)$ & $(0.02580)$ & $(0.01760)$ & $(0.01950)$ \\
\hline Root MSE & 0.0039 & 0.0098 & 0.0067 & 0.0074 \\
\hline$R^{2}$ & 1.00 & 0.99 & 0.99 & 0.99 \\
\hline$R^{2}$-adj & 0.99 & 0.99 & 0.99 & 0.99 \\
\hline
\end{tabular}


Table 10 Detailed results - chocolate muesli

\begin{tabular}{|c|c|c|c|c|}
\hline & Brand 1 & $\begin{array}{l}\text { Private label } \\
\text { regular }\end{array}$ & $\begin{array}{l}\text { Private } \\
\text { label } \\
\text { choco }\end{array}$ & Brand 2 \\
\hline Initial share of calories & $5.0 \%$ & $63.8 \%$ & $21.3 \%$ & $7.8 \%$ \\
\hline Initial share of sales value & $13.1 \%$ & $46.7 \%$ & $20.8 \%$ & $14.4 \%$ \\
\hline \multicolumn{5}{|l|}{ AID model estimation results } \\
\hline \multirow[t]{2}{*}{$\operatorname{Ln} P_{\text {Brand } 1}$} & -0.2943 & 0.0960 & 0.0640 & 0.1247 \\
\hline & $(0.0142)$ & $(0.0313)$ & $(0.0177)$ & $(0.0510)$ \\
\hline \multirow[t]{2}{*}{ Ln P Private label regular } & 0.6598 & -1.2680 & -0.6039 & 0.4600 \\
\hline & $(0.4612)$ & $(0.9849)$ & $(0.5757)$ & $(1.5450)$ \\
\hline \multirow[t]{2}{*}{ Ln P Private label choco } & -0.4838 & 0.5100 & 0.3138 & 0.1899 \\
\hline & $(0.4055)$ & $(0.8553)$ & $(0.5033)$ & $(1.3312)$ \\
\hline \multirow[t]{2}{*}{ Ln $\mathrm{P}_{\text {Brand2 }}$} & 0.0608 & 0.2019 & 0.1427 & -0.4529 \\
\hline & $(0.0164)$ & $(0.0368)$ & $(0.0205)$ & $(0.0589)$ \\
\hline \multirow[t]{2}{*}{ Ln $P_{\text {Brand } 3}$} & -0.0400 & 0.1023 & 0.1085 & 0.1572 \\
\hline & $(0.0692)$ & $(0.1513)$ & $(0.0869)$ & $(0.2413)$ \\
\hline \multirow[t]{2}{*}{ Real budget } & -0.0257 & -0.0966 & -0.0236 & 0.1380 \\
\hline & $(0.0128)$ & $(0.0260)$ & $(0.0149)$ & $(0.0413)$ \\
\hline \multirow[t]{2}{*}{ Reformulation dummy } & -0.0466 & 0.0570 & 0.0191 & -0.0157 \\
\hline & $(0.0334)$ & $(0.0640)$ & (0.0383) & $(0.0992)$ \\
\hline \multirow[t]{2}{*}{ Trend } & 0.0000 & 0.0002 & 0.0009 & -0.0007 \\
\hline & $(0.0008)$ & $(0.0004)$ & $(0.0003)$ & $(0.0006)$ \\
\hline \multirow[t]{2}{*}{ Christmas dummy } & 0.0109 & 0.0096 & -0.0012 & 0.0165 \\
\hline & $(0.0122)$ & $(0.0188)$ & $(0.0126)$ & $(0.0272)$ \\
\hline \multirow[t]{2}{*}{ AR (1) } & 0.8022 & 0.2210 & 0.4339 & 0.0640 \\
\hline & (0.1019) & $(0.1694)$ & $(0.1517)$ & $(0.1668)$ \\
\hline \multirow[t]{2}{*}{ Intercept } & 0.7431 & 2.3112 & 0.2789 & -2.4491 \\
\hline & $(0.4261)$ & $(0.9154)$ & $(0.5233)$ & (1.4814) \\
\hline Root MSE & 0.0148 & 0.0262 & 0.0159 & 0.0413 \\
\hline$R^{2}$ & 0.94 & 0.85 & 0.81 & 0.89 \\
\hline$R^{2}$-adj & 0.92 & 0.81 & 0.76 & 0.86 \\
\hline
\end{tabular}

\section{Acknowledgements}

The REMA1000 retail chain is acknowledged for providing access to the data, TrygFonden is acknowledged for providing financial support for the research, and project head Gitte Laub Hansen, Danish Cancer Society is acknowledged for her constructive comments to earlier drafts of the manuscript.

\section{Funding}

The research and preparation of the paper has been funded by a research grant from TrygFonden. TrygFonden has not been involved in the analysis nor in preparation of the manuscript.

\section{Availability of data and materials}

Data has been made available for this study by a private retailing company (REMA1000) on the condition that the data material is not made public in its raw form.

\section{Authors' contributions}

JDJ has designed and conducted the statistical analysis and drafted the manuscript. IS has collected and prepared data for the analysis and participated in planning of the study and preparation of the manuscript. Both authors read and approved the final manuscript.

\section{Ethics approval and consent to participate}

Not Applicable.

\section{Consent for publication}

Not Applicable.

\section{Competing interests}

Both authors declare to have no competing interests.

\section{Publisher's Note}

Springer Nature remains neutral with regard to jurisdictional claims in published maps and institutional affiliations.

\section{Author details}

${ }^{1}$ University of Copenhagen, Department of Food and Resource Economics, Rolighedsvej 25, 1958 Frederiksberg C, Denmark. ${ }^{2}$ Danish Cancer Society, Strandboulevarden 49, 4100 København Ø, Copenhagen, Denmark.

Received: 20 December 2016 Accepted: 31 July 2017

Published online: 23 August 2017

References

1. Raaij JV, Hendriksen M, Verhagen H. Potentials for improvement of population diet through reformulation of commonly eaten foods. Public Health Nutr. 2009;12(3):325-30.

2. Mancino L, Kuchler F, Leibtag E. Getting consumers to eat more wholegrains: the role of policy, information, and food manufacturers. Food Policy. 2008:33:489-96. http://www.sciencedirect.com/science/article/pii/ S0306919208000535

3. Downs SM, Thow AM, Leeder SR. The effectiveness of policies for reducing dietary trans fat: a systematic review of the evidence. Bull World Health Org. 2013;91:4

4. Webster JL, Dunford EK, Hawkes C, Neal BC. Salt reduction initiatives around the world. J Hypertens. 2011;29(6):1043-50.

5. Wyness LA, Butriss JL, Stanner SA. Reducing the population's sodium intake: the UK Food Standards Agency's salt reduction programme. Public Health Nutr. 2012;15(2):254-61.

6. Monge-Rojas R, Colón-Ramos U, Jacoby E, Mozaffarian D. Voluntary reduction of trans-fatty acids in Latin America and the Caribbean: current situation. Rev Panam Salud Publica. 2011;29(9):126. http://dx.doi.org/10. 1590/S1020-49892011000200008

7. Stender S, Astrup A, Dyerberg J. What went in when trans went out? N Engl Med. 2009:361:314-6. http://dx doi.org/10.1056/NEJMc0903380

8. Keast DR, Rosen RA, Arndt EA, Marquart LF. Dietary modeling shows that substitution of whole-grain for refined-grain ingredients of foods commonly consumed by US children and teens can increase intake of whole grains. J Am Diet Assoc. 2011;111:1322-8.

9. Golan E, Unnevehr L. Food product composition, consumer health, and public policy: introduction and overview of special section. Food Policy. 2008:33:465-9.

10. Unnevehr L, Jagmanaite E. Getting rid of trans fats in the US diet: policies, incentives and progress. Food Policy. 2008;33:497-503.

11. Marotta G, Simeone M, Nazzaro C. Product reformulation in the food system to improve food safety. Evaluation of policy interventions, Appetite. 2014;74 $107-15$

12. Ronit K. and Jensen J.D. (2014) Obesity and industry self-regulation: a literature review, Eur J Clin Nutr , (http://www.nature.com/ejcn/journal/ vaop/ncurrent/pdf/ejcn201460a.pdf).

13. Morgenstern H. (1995) Ecologic studies in epidemiology: concepts, principles and methods, annual review of public health, 16, 61-81.14.Deaton a. \& Muellbauer J. An almost ideal demand system. Am Econ Rev. 1980;70(3):312-26

14. Buttriss JL. Food reformulation: the challenges to the food industry proceedings of the nutrition society. Cambridge Journals Online. 2012;72(1): 61-9. http://journals.cambridge.org/action/displayAbstract?fromPage= online\&aid $=8822959 \&$ fileld $=$ S0029665112002868 
15. Dötsch M, Busch J, Batenburg M, Lien G, Tarelius E, Mueller R, Meijer G. Strategies to reduce sodium consumption: a food industry perspective. CRC Crit Rev Food Sci Nutr. 2009;49(10):841-51.

16. Girgis S, Neal B, Prescott J, Pendergast J, Dumbrell S, Turner C, Woodward M. A one-quarter reduction in the salt content of bread can be made without detection. Eur J Clin Nutr. 2003;57:616-20.

17. Grasso S, Brunton NP, Lyng JG, Lalor F, Monahan FJ. Healthy processed meat products - regulatory, reformulation and consumer challenges, Trends in Food Science and Technology. 2014;39(1):4-17.

18. Edgerton DL. Weak separability and the estimation of elasticities in multistage demand systems. Am J Agri Econ. 1997;79:62-79.

Submit your next manuscript to BioMed Central and we will help you at every step:

- We accept pre-submission inquiries

- Our selector tool helps you to find the most relevant journal

- We provide round the clock customer support

- Convenient online submission

- Thorough peer review

- Inclusion in PubMed and all major indexing services

- Maximum visibility for your research

Submit your manuscript at www.biomedcentral.com/submit
) Biomed Central 